\title{
Asymptomatic bacteriuria: predisposing factors and correlation with preterm labor in low resource settings
}

\author{
Meenakshi Lallar $^{1}$, Anam ul Haq ${ }^{1}$, Rajesh Nandal ${ }^{2}$
}

\author{
${ }^{1}$ Department of Obstetrics and Gynecology, SHKM Medical College, Mewat, Haryana, India \\ ${ }^{2}$ Department of Pediatrics, Artemis Health Institute, Gurgaon, Haryana, India
}

Received: 26 April 2014

Accepted: 4 May 2014

\author{
*Correspondence: \\ Dr. Meenakshi Lallar, \\ E-mail: meenakshilallar@gmail.com
}

(C) 2014 Lallar M et al. This is an open-access article distributed under the terms of the Creative Commons Attribution Non-Commercial License, which permits unrestricted non-commercial use, distribution, and reproduction in any medium, provided the original work is properly cited.

\begin{abstract}
Background: Infection of urinary tract occurs frequently during pregnancy ranging from Asymptomatic Bacteriuria (ASB) to potentially life threatening acute pyelonephritis. The incidence varies from $5 \%$ to $20 \%$ and it is an important risk factor for preterm labor and perinatal morbidity and mortality. The present study was performed to correlate preterm labor and to define other risk factors associated with ASB like gravida status, socioeconomic status, and anaemia in pregnant women with ASB in low resource settings.

Methods: A total of 1000 pregnant mothers in second and third trimester of pregnancy were screened for ASB by using two rapid reagent strip tests, namely nitrate and leukocyte esterase reagent strip tests. Out of those screened positive hundred consecutive pregnant women were taken as cases, after positive urine culture and out of those screened negative, two hundred patients were followed as controls after matching and pairing with cases. A detailed history was taken from each patient to determine all risk factors for ASB. The cases and controls were followed prospectively till delivery.

Results: Mean gestational age at the time of labor in 100 cases of ASB was $35.6 \pm 2.9$ weeks and in 200 controls was $37.9 \pm 0.6$ weeks. The difference between mean gestational age at the time of labor in cases and controls was statistically significant ( $\mathrm{P}$ value 0.000$)$. The likelihood of preterm labor in the cases was 14.5 times more than the control and the difference was significant $(\mathrm{P}<0.05)$.

Conclusions: ASB leads to a higher rate of preterm labor and is more frequently seen in population with anemia, illiteracy, rural background and low socioeconomic status.
\end{abstract}

Keywords: Asymptomatic bacteriuria, Pregnancy, preterm Labor, anemia, Low socioeconomic status

\section{INTRODUCTION}

Infection of the urinary tract occurs frequently during pregnancy and ranges from Asymptomatic Bacteriuria (ASB) to potentially life threatening acute pyelonephritis. ${ }^{1}$ ASB is defined as presence of $\geq 10^{5}$ organism of same species per $\mathrm{ml}$ of urine in an otherwise asymptomatic woman in two consecutive midstream clean catch urine specimens. ${ }^{2}$ For urine collected via bladder catheterization, the threshold is 100 colony forming units of a single species per milliliter. ${ }^{3}$ Although two urine specimens are the gold standard, a single midstream specimen with bacterial species is isolated in a concentration greater than $10^{5}$ colony-forming units per milliliter of urine is a more practical alternative. However, if positive it is estimated that there is $80 \%$ probability that the woman has true bacteriuria, whereas for two specimens, it estimated at $95 \%$ probability. ${ }^{4}$ The physiological changes during pregnancy and short urethra predispose women to bacteriuria. The incidence varies and is about $5 \%$ in general population. About $5 \%$ women are positive for the first time when screened. 
Subsequently $1.5 \%$ are added to the increase the incidence to $6.5 \%$. If untreated $25-40 \%$ of them will develop symptomatic urinary tract infection spreading to upper urinary tract to cause acute pyelonephritis and $40 \%$ will involve lower urinary tract symptoms in the form of acute cystitis. ${ }^{5}$

A major study comparing normal and high risk pregnant women reported $6 \%$ prevalence in healthy women; $12.2 \%$ rate in diabetic women and $18.7 \%$ in women with previous history of urinary tract infection. ${ }^{6}$

There are a number of conditions associated with ASB in pregnancy. Lower socio-economic status, immunesuppression, sickle cell trait, diabetes mellitus, multiparity, anaemia have been reported; each is associated with two fold increase in the rate of bacteriuria. ASB is an important risk factor for preterm labor and perinatal mortality. ${ }^{2}$ ASB also leads to other less favourable pregnancy outcomes and complications like preterm premature rupture of membranes, low birth Weight, preeclamptic toxaemia and anaemia of pregnancy. The present study aimed at quantifying risk of preterm labor in pregnant women with ASB and to define other risk factors associated with ASB like gravida status, socioeconomic status, and anaemia.

\section{METHODS}

The present prospective nested cohort study was carried out in the department of obstetrics and gynecology, SHKM medical college, Mewat Haryana. Patients of the study group and the control were matched on the basis of:

1. Blood pressure within normal limit

2. Age (+ 2 years to 5 years)

3. Gravid (primigravida, multigravida, grand multigravida)

4. Economic class (rich, middle and poor)

5. Gestational age (second trimester or third trimester).

\section{Exclusion Criteria}

1. Patients with superimposed hypertensive disorders or chronic hypertension or a history of renal, cardiovascular and liver diseases.

2. Patients with other risk factors associated with preterm labor like multiple pregnancy, hydramnios, antepartum hemorrhage, cervical incompetence or cervical insufficiency.

3. Patients with (a) history of fever $\left(>38^{\circ} \mathrm{C}\right)$; (b) with two of the following genitourinary complaints (i) dysuria, (ii) urinary hesitancy, (iii) urgency, (iv) slow stream, (v) incontinence, (vi) frequency, (vii) incomplete voiding, (viii) flank, (ix) suprapubic, (x) hypogastric pain; (c) patients with intake of antibiotics for indication during current pregnancy.

A total of 1000 pregnant mothers in second and third trimester of pregnancy were screened for ASB by using two rapid reagent strip tests, namely nitrate and leukocyte esterase reagent strip tests. Out of those screened positive hundred consecutive pregnant women were taken as cases, after positive urine culture and out of those screened negative, two hundred patients were followed as controls after matching and pairing with cases.

Thus the cases were those participants who had urine culture positive of a single midstream clean catch urine specimen and were labeled as cases of - ASB with presence of $>10^{5} / \mathrm{ml}$ cfu (colony forming units). A detailed and comprehensive history was taken from each patient. The cases and controls were followed prospectively till delivery to see the preterm labor as pregnancy outcome in order to judge the significance of association between ASB in pregnancy and preterm labor. Preterm labor was considered to be established, if regular uterine contractions were documented at least 4 in 20 minutes or 8 in 60 minutes with progressive change in the cervical score in the form of effacement of $80 \%$ or more and cervical dilatation greater than $1 \mathrm{~cm}$.

The data of the cases and controls was analyzed as percentages; using descriptive statistics. Comparative evaluation was done using odds ratio, relative risk. All $\mathrm{P}$ values of $<0.05$ were taken as significant. The software used for data analysis was Statistical Package for Social Sciences (SPSS) version 11.5, Minitab and Microsoft excel.

\section{RESULTS}

The majority of pregnant women in the cases $(50 \%)$ were in the age group of 25 to 29 years. In the control group also, majority $(67.5 \%)$ were in the same age group of 25 to 29 years. In the cases, $46 \%$ patients were in the group of 30 to 34 years; $3 \%$ in age group 20 to 24 years and $1 \%$ in age group 35 to 39 years. In the control group $25.5 \%$, patients were in the age group of 30 to 34 years; $0.5 \%$ in age group 20 to 24 years and $6.5 \%$ in the age group of 35 to 39 years. Thus, the mean age in the cases was $29.2 \pm$ 2.6 years and in the control group was $28.9 \pm 2.7$ years. There was no significant difference in the age profile of the two groups $(\mathrm{P}=0.250)$

In the cases, 94\% (majority) of the subjects were illiterate, $6 \%$ were matric whereas in the control group $76 \%$ were illiterate and $24 \%$ literate (Table 1 ).

In the cases, $93 \%$ were from rural population and only $7 \%$ were urban dwellers, whereas in the control group, $81 \%$ were rural dwellers and $19 \%$ urban population (Table 1). 
Mean family income of the cases in Indian rupees was $7490.0 \pm 6738.2$ and in the control group was $7961.0 \pm$ 5442.5 (Table 1).

In the cases, $62 \%$ subjects belonged to household group and $53.5 \%$ subjects in the control group belonged to household group (Table 1).
In the cases, according to modified Kuppuswamy scale of socioeconomic status 2007 most of the subjects $73 \%$ belonged to the upper lower class, $7 \%$ belonged to the lower class (total $80 \%$ belonged to the lower class) as compared to $67.5 \%$ in the control group. The difference between the Socio-economic status of the study and the control group was statistically significant ( $\mathrm{P}$ value 0.028 ). Thus ASB occurs more in lower socioeconomic class (Table 1).

Table 1: Socio-demographic characteristics of the pregnant women with asymptomatic bacteriuria.

\begin{tabular}{|c|c|c|c|c|c|c|}
\hline \multirow{2}{*}{ Characteristic } & & \multicolumn{2}{|c|}{ Study } & \multicolumn{2}{|c|}{ Control } & \multirow{2}{*}{ P value } \\
\hline & & $\mathbf{n}$ & $\%$ & $\mathbf{n}$ & $\%$ & \\
\hline \multirow{6}{*}{ Literacy status } & Illiterate & 94 & 94.0 & 152 & 76 & \multirow{6}{*}{$0.000\left(\right.$ Sig) ${ }^{*}$} \\
\hline & Primary & 0 & 0.0 & 4 & 2 & \\
\hline & Secondary & 0 & 0.0 & 13 & 6.5 & \\
\hline & Matric & 6 & 6.0 & 19 & 9.5 & \\
\hline & Graduate & 0 & 0.0 & 11 & 5.5 & \\
\hline & $\begin{array}{l}\text { Postgraduate/ } \\
\text { Professional }\end{array}$ & 0 & 0.0 & 1 & 0.5 & \\
\hline \multirow{2}{*}{ Dwelling } & Rural & 93 & 93.0 & 162 & 81.0 & \multirow{2}{*}{$0.006(\mathrm{Sig}) *$} \\
\hline & Urban & 7 & 7.0 & 38 & 19.0 & \\
\hline \multirow{4}{*}{ Family income (Rs.) } & $<5000$ & 18 & 18.0 & 36 & 18.0 & \multirow{4}{*}{$0.220(\mathrm{NS}) \dagger$} \\
\hline & 5000 to 10000 & 76 & 76.0 & 135 & 67.5 & \\
\hline & $\geq 10000$ & 6 & 6.0 & 29 & 14.5 & \\
\hline & Mean \pm SD & \multicolumn{2}{|c|}{$\begin{array}{l}7490.0 \pm 6738.2 \\
(3000,60000)\end{array}$} & \multicolumn{2}{|c|}{$\begin{array}{l}7961.0 \pm 5442.5 \\
(3000,50000)\end{array}$} & \\
\hline \multirow{5}{*}{ Occupation } & Household & 62 & 62.0 & 107 & 53.5 & \multirow{5}{*}{$0.106(\mathrm{NS}) \dagger$} \\
\hline & Unskilled & 14 & 14.0 & 34 & 17.0 & \\
\hline & Semiskilled & 18 & 18.0 & 30 & 15.0 & \\
\hline & Skilled & 6 & 6.0 & 27 & 13.5 & \\
\hline & Professional & 0 & 0.0 & 2 & 1.0 & \\
\hline \multirow{5}{*}{ Socio-economic status } & Lower & 7 & 7.0 & 13 & 6.5 & \multirow{5}{*}{$0.028(\mathrm{Sig})^{*}$} \\
\hline & Upper lower & 73 & 73.0 & 122 & 61.0 & \\
\hline & Middle & 18 & 18.0 & 47 & 23.5 & \\
\hline & Upper middle & 2 & 2.0 & 17 & 8.5 & \\
\hline & Upper & 0 & 0.0 & 1 & 0.5 & \\
\hline
\end{tabular}

*Significant, $\uparrow$ Not Significant

Around $33 \%$ of the patients in the cases were gravida 4 , $19 \%$ gravida $3,31 \%$ gravida 2 and $17 \%$ gravida 1 . In the control group, $35.5 \%$ were gravida $2,17 \%$ were gravida $3,27.0 \%$ were gravida 4 and $20.5 \%$ were gravida 1 . Thus, the distribution in obstetric history among the cases and controls was uniform in our study which avoided bias in the study $(\mathrm{P}=0.196$ not significant $)$.

Out of all the subjects (study + control group); $29.31 \%$ gravida 1 had ASB, $30.39 \%$ gravida 2 had ASB and $35.84 \%, 37.93 \%$ gravida 3 and gravida 4 had ASB. Thus,
ASB was found more in higher order of gravida status subjects in our study.

Mean gestational age in weeks in the cases at the time of Dipstick examination was $31.3 \pm 1.0$ weeks and in the control group was $31.3 \pm 1.4$ weeks and the difference among the two groups was statistically non-significant $(\mathrm{P}$ $=0.724)$. This depicts that the dipstick test was done at the same mean gestational age in the cases and controls to avoid bias in the study. 
In the cases, the mean haemoglobin level in gm\% was 7.5 \pm 0.6 and in the control group was $7.9 \pm 0.5$. The difference was statistically significant ( $\mathrm{P}$ value 0.000 ). This means that ASB occurs more in anaemic subjects.

Dipstick test was positive in 432 screened patients and urine culture was positive in 160 women. The urine culture of the cases showed the most common organism as E. coli causing ASB. E. coli was found in $69 \%$ of the cases. Coagulase negative staphylococcus was positive in $11 \%$, Staphylococcus aureus was found in $11 \%$, Klebsiella in $4 \%$ and Enterobacter in $5 \%$ of the cases.

Mean gestational age at the time of labor in 100 cases of ASB was $35.6 \pm 2.9$ weeks and in 200 controls was 37.9 \pm 0.6 weeks. The difference between mean gestational age at the time of labor in cases and controls was statistically significant ( $P$ value 0.000). The cases presented to us in labor at a lower mean gestational age i.e. with preterm labor.

Out of 100 patients with significant ASB; 31 presented with preterm labor and out of 200 controls; only 6 presented with preterm labor. The results were statistically significant ( $\mathrm{P}$ value 0.000 ). The likelihood of preterm labor in the cases was 14.5 times more than the control and the difference was significant $(\mathrm{P}<0.05)$. The cases had relative risk of 3.2 of developing preterm labor. Among the cases, $31 \%$ subjects had preterm labor whereas in the control group, only $3 \%$ subjects had preterm labor. Thus, the difference was statistically significant $(\mathrm{P}<0.05)$ (Table 2).

Table 2: Preterm labor in pregnant women with asymptomatic bacteriuria.

\begin{tabular}{|llllll|}
\hline Preterm & \multicolumn{2}{l}{ Study } & \multicolumn{2}{c|}{ Control } & \multirow{2}{*}{ P value } \\
labor & n & \% & n & \% & \\
\cline { 1 - 5 } Yes & 31 & 31.0 & 6 & 3.0 & \multirow{2}{*}{$0.000(\mathrm{Sig}) *$} \\
\hline No & 69 & 69.0 & 194 & 97.0 & \\
\hline
\end{tabular}

*Significant, $\mathrm{OR}=14.5, \mathrm{RR}=3.2, \mathrm{PPV}=83.8 \%, \mathrm{NPV}=73.8 \%$

Likelihood of preterm labor among the study group mothers $\geq 30$ years of age was 1.9 times more than the mothers bearing $<30$ years of age. RR was 1.6 and the difference was not statistically significant $(\mathrm{P}>0.05)$.

Asymptomatic bacteriuria was more in patients with gravida status $>2$ being $37.14 \%$. Thus, ASB is associated more with the higher gravida status.

When ASB in pregnancy with literacy status of all studied subjects was compared, we clearly get results that ASB is more in illiterate subjects with $\mathrm{p}$ value being 0.000 which is statistically significant $(\mathrm{P}<0.05)$ (Table $3)$.
The likelihood of rural population is more in rural dwellers with statistically significant $\mathrm{P}$ value 0.006 ( $\mathrm{P}$ $<0.05$ ) (Table 4).

ASB was more in upper lower class with $\mathrm{P}$ value statistically significant 0.028 ( $\mathrm{P}<0.05)$ (Table 5).

Table 3: Relationship of asymptomatic bacteriuria in pregnancy with literacy status of studied subjects.

\begin{tabular}{|llllll|}
\hline $\begin{array}{l}\text { Literacy } \\
\text { status }\end{array}$ & $\begin{array}{l}\text { Cases } \\
\text { (Asymptomatic } \\
\text { bacteriuria } \\
\text { positive) }\end{array}$ & $\begin{array}{l}\text { Control group } \\
\text { (Asymptomatic } \\
\text { bacteriuria } \\
\text { negative) }\end{array}$ & $\begin{array}{l}\text { P } \\
\text { value }\end{array}$ \\
\cline { 1 - 5 } Illiterate & 94 & 94.0 & n & $\%$ & \\
\hline Literate & 6 & 6.0 & 48 & 76 & 0.000 \\
(Sig)
\end{tabular}

*Significant

Table 4: Relationship of asymptomatic bacteriuria with dwelling status of studied subjects.

\begin{tabular}{|c|c|c|c|c|c|}
\hline \multirow[t]{2}{*}{$\begin{array}{l}\text { Dwelling } \\
\text { Status }\end{array}$} & \multicolumn{2}{|c|}{$\begin{array}{l}\text { Cases } \\
\text { (Asymptomatic } \\
\text { bacteriuria } \\
\text { positive) }\end{array}$} & \multicolumn{2}{|c|}{$\begin{array}{l}\text { Control group } \\
\text { (Asymptomatic } \\
\text { bacteriuria } \\
\text { negative) }\end{array}$} & \multirow[t]{2}{*}{$\begin{array}{l}\mathbf{P} \\
\text { value }\end{array}$} \\
\hline & $\mathbf{n}$ & $\%$ & $\mathbf{n}$ & $\%$ & \\
\hline Rural & 93 & 93.0 & 162 & 81.0 & \multirow{2}{*}{$\begin{array}{l}0.006 \\
(\mathrm{Sig})^{*}\end{array}$} \\
\hline Urban & 7 & 7.0 & 38 & 19.0 & \\
\hline
\end{tabular}

*Significant

Table 5: Relationship of asymptomatic bacteriuria in pregnancy with socio-economic status of studied subjects.

\begin{tabular}{|c|c|c|c|c|c|}
\hline \multirow[t]{2}{*}{$\begin{array}{l}\text { Socio- } \\
\text { economic } \\
\text { Status }\end{array}$} & \multicolumn{2}{|c|}{$\begin{array}{l}\text { Cases } \\
\text { (Asymptomatic } \\
\text { bacteriuria } \\
\text { positive) }\end{array}$} & \multicolumn{2}{|c|}{$\begin{array}{l}\text { Control group } \\
\text { (Asymptomatic } \\
\text { bacteriuria } \\
\text { negative) }\end{array}$} & \multirow[t]{2}{*}{$\begin{array}{l}\mathbf{P} \\
\text { value }\end{array}$} \\
\hline & $\mathbf{n}$ & $\%$ & $\mathbf{n}$ & $\%$ & \\
\hline Lower & 7 & 7.0 & 13 & 6.5 & \multirow{5}{*}{$\begin{array}{l}0.028 \\
(\mathrm{Sig})^{*}\end{array}$} \\
\hline $\begin{array}{l}\text { Upper } \\
\text { lower }\end{array}$ & 73 & 73.0 & 122 & 61.0 & \\
\hline Middle & 18 & 18.0 & 47 & 23.5 & \\
\hline $\begin{array}{l}\text { Upper } \\
\text { middle }\end{array}$ & 2 & 2.0 & 17 & 8.5 & \\
\hline Upper & 0 & 0.0 & 1 & 0.5 & \\
\hline
\end{tabular}

*Significant

\section{DISCUSSION}

The present study revealed a significant increase in the number of preterm births in pregnant women with ASB. Also the study showed that anemia, lower socioeconomic status, multiparity, illiteracy and rural dwellings as a predisposing factor for ASB. Dipstick test was positive in 
432 screened patients and urine culture was positive in 160 women. Thus dipsticks are a less sensitive and less specific; urine culture was the gold standard. ${ }^{7}$

The prevalence of ASB in pregnant women was $16 \%$. As also seen in our study, the most common organism causing both ASB and symptomatic bacteriuria is Escherichia Coli accounting for $80-90 \%$ of cases and other organisms include Klebsiella, Enterobacter, Proteus, Enterococcus faecalis, Group B Streptococcus (GBS) and Staphylococcus saprophyticus.

The bacteria causing infections of urinary tract originally reside in the rectal/anal area and from there colonize the perineum, vaginal introitus, urethra, bladder and eventually the pelvicalyceal area and kidney itself. The physiological changes during pregnancy and short urethra predispose women to bacteriuria. It is conceivable that urinary tract infection affects premature labor directly. One hypothesis contends that bacterial enzymes such as collagenase may weaken the foetal membranes and predispose them to rupture, which subsequently triggers the onset of labor. ${ }^{8}$ It has also been postulated that bacterial products such as Phospholipase A and C or endotoxins may stimulate prostaglandin biosynthesis by foetal membranes; which then initiates labor. Alternatively, these bacterial products might simulate the release of monokines (particularly platelet activating factor, interleukin-1 and Tumour Necrosis factor) that then trigger prostaglandin production. ${ }^{9}$

The relationship between ASB in pregnancy with adverse pregnancy outcomes was first suggested by Kass in 1959 . Various studies over time have proved relation between ASB and preterm labor. ${ }^{9-14}$

However in the developing countries, there is a significant controversy regarding the cost effectiveness of the routine screening in pregnancy for ASB. It is said to be cost effective if the pregnant population is showing an incidence of more than $10 \%$ that is high risk. In low risk that is less than $5 \%$ incidence it is not cost effective. ${ }^{15}$ However in our scenario where prevalence of ASB was high it would be cost effective to screen the pregnant women for ASB.

Based on the above observations, it is concluded that there is a definite correlation between ASB in pregnancy with preterm labor. ASB is a hidden problem and leads to significant adverse pregnancy outcome of preterm labor and increased perinatal morbidity. ASB is found more with anemia, low socioeconomic status and increasing pregnancy order. These should thus be corrected to decrease the burden of ASB and improve the fetomaternal outcome in populations with low resource set up. It should be screened in pregnancy to lower the preterm labor. However it is not clear and more studies are needed to determine best timing, best diagnostic method, frequency of testing in women with positive and negative results and duration of treatment.
Funding: No funding sources Conflict of interest: None declared

Ethical approval: The study was approved by the hospital ethical committee

\section{REFERENCES}

1. Ahmed S, Rashid H U. Urinary tract Infection in Adults: A Review. Bangladesh Renal J. 1996;15:2331.

2. Klein laura L, Gibbs Ronald S. Use of microbial cultures and antibiotics in the prevention of infection associated preterm birth. Am J Obstet Gynecol. 2004;190(6):1493-502.

3. Guinto VT, De Guia B, Festin MR, Dowswell T. Different antibiotic regimens for treating asymptomatic bacteriuria in pregnancy. Cochrane Database Syst Rev. 2010;(9):CD007855.

4. Smaill FM, Vazquez JC. Antibiotics for asymptomatic bacteriuria in pregnancy. Cochrane Database Syst Rev. 2007;(2):CD000490.

5. Scott JR. Medical and Surgical complications of pregnancy. In: Scott JR, Gibbs RS, Karlon BY, Haney AF, eds. Danforth's Obstetrics and Gynecology. 9th ed. Philadelphia: Lippincott Williams and Wilkins; 2003: 292-294.

6. Fitzgerald MA. Urinary tract infection: providing the best care, 2002. Available at: http:/www.medscape.com/viewarticle/436592. Assessed 10 March 2014.

7. Mignini L, Carroli G, Abalos E, Widmer M, Amigot S, Nardin JM et al. World Health Organization asymptomatic bacteriuria trial group. Accuracy of diagnostic tests to detect asymptomatic bacteriuria during pregnancy. Obstet Gynecol. 2009;113:346-52.

8. Akerele J, Abhulimen P, Okonofua F. Prevalence of asymptomatic bacteriuria among pregnant women in Benin City, Nigeria. J Obstet Gynecol. 2001;21:1414.

9. Lin Kenneth MD and Fajardo Kevin. Screening for asymptomatic bacteriuria in adults: U. S. preventive services task force recommendations. Ann Intern Med. 2008;149:20-4.

10. Uncu Y, Uncu G, Esmer A, Bilgel N. Should asymptomatic bacteriuria be screened in pregnancy? Clin Exp Obstet Gynecol. 2002;29(4):281-5.

11. Deville Walter LJM, Zermans Joris CY, Duijn Nico P. Van, Bezemer P. Dick, Vanderwindt Danielle AWM , Bouter Lex M. The Urine dipstick test useful to rule out infections. A meta-analysis of the accuracy. BMC Urol. 2004;4(3):4.

12. Versi E, Chia P, Griffiths DJ, Harlow BL. Bacteriuria in pregnancy: a comparison of Bangladeshi and Caucasian women. Int Urogynecol J. 1997;8(1):8-12.

13. Levent $\mathrm{T}$, Nurittin A, Ercument M, Rustu EA, Yergok YZ. Urinary tract infection in pregnancy. Perinatal J. 2005;13:47.

14. Jain V, Das V, Agarwal A, Pandey A. Asymptomatic bacteriuria and obstetric outcome 
following treatment in early versus late pregnancy in north Indian women. Indian $\mathrm{J}$ Med Res. 2013;137(4):753-8.

15. Cunningham FG, Steer P. Urinary tract in pregnancy. In: Cunningham FG, Steer P, eds. Turnbull's
Obstetrics. 3rd ed. Edinburgh: Churchill Livingstone; 2001: 383-402.

DOI: $10.5455 / 2320-1770 . i j \operatorname{rog} 20140624$

Cite this article as: Lallar M, Haq A, Nandal R. Asymptomatic bacteriuria: predisposing factors and correlation with preterm labor in low resource settings. Int J Reprod Contracept Obstet Gynecol 2014;3:403-8 